\title{
Similarity of osmoregulatory capacity in coastal and inland alligator gar
}

\author{
Peter J. Allen ${ }^{\mathrm{a}, *}$, Alf Haukenes ${ }^{\mathrm{b}}$, Steve E. Lochmann ${ }^{\mathrm{b}}$ \\ a Department of Wildlife, Fisheries and Aquaculture, Mississippi State University, PO Box 9690, Mississippi State, MS 39762, United States \\ b Center for Aquaculture and Fisheries, University of Arkansas Pine Bluff, PO Box 4912, Pine Bluff, AR 71601, United States
}

\section{A R T I C L E I N F O}

\section{Keywords:}

Niche conservatism

Primitive

Physiological capacity

Fish

Osmoregulation

Gar

Temperature

Salinity

\begin{abstract}
A B S T R A C T
The alligator gar Atractosteus spatula is a primitive fish species, occupying a wide range of temperature and salinity habitats. Long-distance movements are limited, leading to genetic differentiation between inland and coastal populations. Unknown is whether physiological capacity differs between geographically separated populations, particularly for traits important to osmoregulation in saline environments. Alligator gar from inland and coastal populations were reared in a similar environment and exposed to temperature $\left(10,30{ }^{\circ} \mathrm{C}\right)$ and salinity $(0,20 \mathrm{ppt})$ extremes to determine whether iono- and osmoregulatory ability differed between populations. There were few differences in osmoregulatory ability between populations, with similar gill, blood and gastrointestinal tract osmoregulatory parameters. Blood plasma osmolality, ion concentrations, intestinal $\mathrm{pH}$ and bicarbonate base concentrations, intestinal fluid osmolality, ion concentrations and gill $\mathrm{Na}^{+}, \mathrm{K}^{+}-\mathrm{ATPase}$ (NKA) activity were similar between populations. Notably, gar from both populations did not osmoregulate well at low temperature and high salinity, with elevated plasma osmolality and ion concentrations, low gill NKA, and little evidence of gastrointestinal tract contribution to ionic and base regulation based on a lack of intestinal fluid and low base content. Therefore, the hypothesis that coastal gar would have improved osmotic regulatory ability in saline environments as compared to inland alligator gar was not supported, suggesting physiological capacity may be retained in primitive species possibly due to its importance to their persistence through time.
\end{abstract}

\section{Introduction}

Physiological capacity is important for establishing the abiotic limits of a species niche, or its fundamental niche (Hutchinson, 1957). Physiological capacity influences the geographic distribution of species (Somero, 2005) and niche dimensions (Vieites et al., 2009), however, its application in understanding genetic divergence is underutilized. Physiological capacity may be challenged in extreme environments encountered at the periphery of a species distribution (Bozinovic et al., 2011). Peripheral habitats are often subject to limited gene flow which may lead to genetic divergence and local adaptation (Thomas et al., 2001; Lenormand, 2002; Bridle and Vines, 2006).

Early fishes form the "trunk" of the vertebrate branch of the phylogenetic tree, with important evolutionary branches deriving from these groups. Interestingly, many of the early fishes have living relatives persisting to the present. Although these living relatives retain many primitive traits, presumably, they continue to evolve to changing environmental conditions. Alternatively, their persistence to the present may be due to limited change in certain physiological traits important to their survival through time, similar to arguments for niche conservatism (Wiens and Graham, 2005).
Temperature and salinity are important abiotic environmental conditions in aquatic habitats, and have led to genetic divergence in populations (Koehn et al., 1980; Bekkevold et al., 2005). Populations tend to diverge at the limits of their distribution where environmental conditions impact the physiological capacity of the organism. For ectothermic organisms such as fishes, temperature has a direct effect on metabolism. At low temperatures metabolic rate is low; however iono- and osmoregulation may become less efficient due to changes in membrane lipids (Hochachka and Somero, 2002). With increasing temperature, metabolic rate increases, although oxygen solubility in water decreases and may limit aerobic capacity (Pörtner and Knust, 2007).

The ability to iono- and osmoregulate constrains fish to different salinity habitats. Most fishes have adaptations for life either in fresh or saline water, with a much smaller subset able to move between saline environments periodically (i.e., diadromous fishes) or regularly (i.e., euryhaline fishes). A number of primitive fishes have the ability to ionoand osmoregulate in environments with lower or higher salinity than their internal blood osmolality (Beamish et al., 1978; Beamish, 1980; Richards and Beamish, 1981; McDowall, 1988, 1997; Allen and Cech, 2007; Allen et al., 2009, 2011; Schwarz and Allen, 2014) including the

\footnotetext{
* Corresponding author.

E-mail address: peter.allen@msstate.edu (P.J. Allen).
} 
gars, members of the family Lepisosteidae.

The gars consist of seven extant species in North and Central America although they were historically much more widely distributed (Wiley, 1976; Wiley and Schultze, 1984; Cavin, 2010; Wright et al., 2012). Of these species, limited available information indicates the alligator gar Atractosteus spatula is likely the most euryhaline species (Suchy, 2009; Schwarz and Allen, 2014), occupying inland and coastal habitats ranging from fresh water to seawater (Suttkus, 1963; Ross, 2001). Most gar species have some capacity for osmotic regulation in saline environments with species reaching larger body sizes apparently having greater salinity tolerance (Goodyear, 1967; Smatresk and Cameron, 1982; Cavin, 2010; McGrath et al., 2012). Alligator gar are long-lived fishes (Ferrara, 2001), living over 60 years (Buckmeier et al., 2012) and reaching body sizes near $3 \mathrm{~m}$ and $140 \mathrm{~kg}$ (Suttkus, 1963; Ross, 2001). Alligator gar occur in the Mississippi River drainage in North America and along the Gulf of Mexico coast (Ross, 2001). Populations are found in both inland freshwater habitats and coastal saline habitats with salinities up to $\geq 32$ ppt (DiBenedetto, 2009). In inland populations, adults occupy freshwater habitats much of the year, and move to freshwater floodplains to spawn (Suttkus, 1963; Ross, 2001; Kluender et al., 2016). In coastal populations, alligator gar may be found in estuarine or marine habitats much of the year, and may spawn in estuarine environments or freshwater habitats (Sakaris et al., 2003; A. Ferrara, Nicholls State University, personal communication). Adults in inland populations have relatively small home ranges, and movements and mixing are apparently limited between populations (Buckmeier et al., 2013; Kluender et al., 2016), in contrast to coastal fish which may move more frequently (Sakaris et al., 2003). Recently, microsatellites were developed for alligator gar (Moyer et al., 2009) and used to identify genetically differentiated populations, indicating differences between inland (Mississippi River drainage) and coastal (northern Gulf of Mexico Coast) populations (Bohn, 2013).

Divergence in osmoregulatory ability is common within closely related species of fishes, and has been documented in teleosts such as salmonids (McCormick, 1994) and killifishes (Griffith, 1974), and primitive fishes such as lampreys (Beamish, 1980). Intraspecific differences in osmoregulatory ability and salinity tolerance have also been identified between populations and found to persist in progeny reared in common garden environments (Purcell et al., 2008). Differences in hypo-osmoregulatory ability between landlocked and anadromous salmonids have been linked to failure to upregulate $\mathrm{Na}^{+}, \mathrm{K}^{+}$ATPase (NKA) and linked to a lack of change in gene expression of isoform $\alpha 1 b$ (Bystriansky et al., 2007). This suggests a genetic basis for divergence in osmoregulatory ability, which has been identified for salmonids (Nichols et al., 2008; Aykanat et al., 2011; Le Bras et al., 2011; Norman et al., 2011) and sticklebacks (DeFaveri et al., 2011). In alligator gar, genetic divergence between inland and coastal populations may indicate iono- and osmoregulatory ability differs between populations. Further, limited ecological evidence indicates coastal populations may spawn in low salinity brackish water (A. Ferrara, Nicholls State University, personal communication) in contrast to freshwater areas in inland populations (Suttkus, 1963). In order to test whether genetic divergence is associated with differences in iono- and osmoregulatory abilities in this primitive fish species, a common environment approach was utilized, with two distinct populations of alligator gar reared in similar conditions and exposed to extreme temperature and salinity environments.

\section{Material and methods}

\subsection{Fish source}

Inland adult alligator gar were collected in the spring from the St. Catherine Creek National Wildlife Refuge, Sibley, Mississippi by the staff of the US Fish and Wildlife Service Private John Allen National Fish Hatchery, Tupelo, Mississippi. One female and two males were artificially induced to spawn using luteinizing hormone releasing hormone analogue, and four day post-hatch larvae were shipped to the University of Arkansas at Pine Bluff Aquaculture/Fisheries Center. Coastal adult alligator gar were collected from the Rockefeller Wildlife Refuge, Grand Chenier, Louisiana by staff of the Louisiana State University Agricultural Center and Nicholls State University during January of the same year. One female and two males were artificially induced to spawn using luteinizing hormone releasing hormone analogue. Larvae-young juveniles were reared using a formulated semi-moist diet (Otohime A, Marubeni Nisshin Feed Co., LTD, Tokyo, Japan) and gradually transitioned to a dry formulated diet (Silver Cup Fish Feed, Murray, Utah, $45 \%$ protein). Three weeks after hatch, fish were transported to the University of Arkansas at Pine Bluff Aquaculture/ Fisheries Center. Although both populations were at different locations for the first 3 weeks of life, importantly, salinities were similar ( $0 \mathrm{ppt}$ ). Because both populations originated from wild fish and induced reproduction techniques are still being developed for this species, exact synchrony of fertilization and hatching was not possible, although both populations hatched within $5 \mathrm{~d}$ of each other (May 2 and 7). After transfer to the common facility, alligator gar from both locations were reared in indoor recirculating systems comprised of three 100-L tanks and a 65-L sump for each population, maintained in the same room at $20{ }^{\circ} \mathrm{C}$, and fed formulated feed (Silver Cup Fish Feed, Murray, Utah, $45 \%$ protein) ad libitum for 9-10 months prior to the present study. This research followed American Fisheries Society Guidelines for the Use of Fishes in Research (Nickum et al., 2004) and institutional animal use protocol \#10-046.

\subsection{Temperature and salinity acclimation}

Both populations of alligator gar were acclimated to two temperature $\left(10\right.$ and $\left.30^{\circ} \mathrm{C}\right)$ and two salinity $(0,20 \mathrm{ppt})$ combinations in recirculation systems for a total of four treatments per population. Each treatment combination had four tanks per population, and two fish were sampled per treatment and population. These conditions represent extreme conditions found in the winter and summer in coastal Texas to Florida (NOAA, 2015), and in the lower Mississippi River (USGS, 2015) and associated drainages (Kluender et al., 2016). Extreme conditions, because of their relevance to distributional limits and local adaptation (Thomas et al., 2001; Lenormand, 2002; Bridle and Vines, 2006), were used to discern whether differences in osmo- and ionoregulatory ability are present between inland and coastal populations. Each recirculation system had eight 75-L acrylic tanks, a 225-L sump with gravel biofilter, a 5- $\mu \mathrm{m}$ cartridge filter, an activated carbon filter, and a 25-watt ultraviolet filter. Recirculation systems were filled with dechlorinated municipal water. Alligator gar (5-8 fish/tank) were placed in systems at room temperature $\left(\sim 20^{\circ} \mathrm{C}\right)$ and held for at least two weeks prior to acclimation, with both populations acclimated to conditions simultaneously in the same system, but in separate tanks. Two recirculating systems were available at one time, so the four treatments were randomized in order. Salinities were adjusted in two systems with Instant Ocean Sea Salt (Spectrum Brands, Blacksburg, Virginia, USA) at a rate of $\sim 4 \mathrm{ppt} / \mathrm{d}$ to $20 \mathrm{ppt}$. Temperatures were adjusted in two systems at a rate of $2{ }^{\circ} \mathrm{C} / \mathrm{d}$ to temperatures of $10^{\circ} \mathrm{C}$ and $30^{\circ} \mathrm{C}$. This created temperature/salinity combinations at 0 and $20 \mathrm{ppt}$ and temperatures of $10^{\circ} \mathrm{C}$ and $30{ }^{\circ} \mathrm{C}$. Fish were held at respective temperature and salinity combinations for 2-4 weeks. Temperature was maintained using immersion heaters (LTA111-R14SS-P1, Process Technology, Mentor, $\mathrm{OH}$, USA) and chillers (barrel system, Pentair Aquatic Eco-systems, Apopka, FL, USA). Temperature and salinity were measured 3-4 times weekly using a YSI85 meter (Yellow Springs, OH, USA). Fish were offered formulated feed (Silver Cup Fish Feed, Murray, Utah, 45\% protein, $7.5 \mathrm{~mm}$, floating) ad libitum throughout the acclimation period, although the low temperature treatments were not observed feeding. Mortality of several fish occurred during the acclimation phase of the $10^{\circ} \mathrm{C}, 20 \mathrm{ppt}$ treatment for both populations, but not in any of the other treatments. 


\subsection{Blood, gastrointestinal tract fluid and gill tissue sampling}

Eight fish were randomly sampled from each population (inland, coastal $) \times$ temperature $\left(10,30^{\circ} \mathrm{C}\right) \times$ salinity treatment $(0,20 \mathrm{ppt})$ combination for a total of 64 fish sampled. For each combination, there were four tanks, in which two fish were sampled for blood, gill tissue and gastrointestinal tract fluid and solids. Prior to sampling, food was withheld for $24 \mathrm{~h}$. Fish were anesthetized in a $200 \mathrm{mg} / \mathrm{L}$ solution of tricaine methanesulphonate in water at their treatment salinity, and weighed to the nearest $0.1 \mathrm{~g}$. Blood was collected from the caudal vasculature using a $3 \mathrm{~mL}$ syringe and 21 gauge $3.8 \mathrm{~cm}$ hypodermic needle coated with lithium heparin. Blood was centrifuged at $9600 \times g$ for $5 \mathrm{~min}$, plasma was removed and frozen at $-20{ }^{\circ} \mathrm{C}$ and then transferred to $-80^{\circ} \mathrm{C}$. After blood sampling, fish were euthanized by pithing. Filament and lamellar gill tissue from the 2nd gill arch were dissected and placed into $2 \mathrm{~mL}$ screw-top microcentrifuge tubes containing $300 \mu \mathrm{L}$ of ice-cold buffer containing $150 \mathrm{mM}$ sucrose, $10 \mathrm{mM}$ ethylene-diaminetetraacetic acid, and $50 \mathrm{mM}$ imidazole (SEI buffer) similar to McCormick (1993), frozen and stored at $-80^{\circ} \mathrm{C}$ prior to analyses.

The gastrointestinal tract was removed by making incisions from the insertion of the pectoral fin to the anus of the fish and from the insertion of the pectoral fin to the midventral line. The gastrointestinal tract was ligated as close to the anus as possible, as close to the anterior most part of the esophagus as possible, and at the junction between the stomach and the intestine, securing the contents separately within the stomach and intestine. The gastrointestinal tract was dissected from the fish, placed in a whirl-pack bag, and frozen at $-20{ }^{\circ} \mathrm{C}$, and then transferred to a $-80^{\circ} \mathrm{C}$ freezer until analysis ( $<3$ months). Immediately prior to analyses, gastrointestinal tracts were thawed, and small incisions were made in the stomach and intestinal portions, and contents were gently squeezed into $1.5 \mathrm{ml}$ microcentrifuge tubes. Contents were centrifuged at $13,000 \times g$ for $5 \mathrm{~min}$ at $4{ }^{\circ} \mathrm{C}$ and then fluid was pipetted into separate $0.6 \mathrm{ml}$ microcentrifuge tubes.

\subsection{Osmolality, ion and $\mathrm{pH}$ measurements}

Osmolality was measured in plasma and gastrointestinal tract fluids using a vapor pressure osmometer (5520, Wescor, Logan, UT, USA). Concentrations of $\mathrm{Na}^{+}, \mathrm{NH}_{4}{ }^{+}, \mathrm{K}^{+}, \mathrm{Mg}^{2+}, \mathrm{Ca}^{2+}, \mathrm{Cl}^{-}, \mathrm{Fl}^{-}, \mathrm{Br}^{-}, \mathrm{NO}_{3}{ }^{-}$, $\mathrm{PO}_{4}{ }^{3-}, \mathrm{SO}_{4}{ }^{2-}$ were measured using an ion chromatography system (DX500, Dionex, Bannockburn, IL, USA). Gastrointestinal tract fluid pH was measured using a $\mathrm{pH}$ meter (AB15 Accumet, Fisher Scientific, Pittsburgh, PA, USA) and a microelectrode (1362096, Accumet, Fisher Scientific).

\subsection{Gastrointestinal tract $\mathrm{HCO}_{3}{ }^{-}$analyses}

Gastrointestinal tract solids and fluids were analyzed for $\mathrm{HCO}_{3}{ }^{-}$base (total $\mathrm{CO}_{2}$ : including $\mathrm{HCO}_{3}{ }^{-}, \mathrm{CO}_{3}{ }^{2-}, \mathrm{CO}_{2}$ ) using a double titration method following Wilson et al. (1996) and Allen et al. (2009). For fluids, $50 \mu \mathrm{l}$ of sample was added to $10 \mathrm{ml}$ of $40 \mathrm{mM} \mathrm{NaCl}$ in a $30 \mathrm{ml}$ glass beaker with a pH electrode (AB15 Accumet, Fisher Scientific, Pittsburgh, PA, USA). The beaker was supplied with a steady, gentle bubbling of nitrogen, and continuously mixed with a magnetic stir bar. Initial $\mathrm{pH}$ was measured, and then $20 \mathrm{mM} \mathrm{HCl}$ was added by pipette to drop the $\mathrm{pH}<4$ and then $20 \mathrm{mM} \mathrm{NaOH}$ was added to return to the initial $\mathrm{pH}$. The differential in the number of moles was equivalent to the number of moles of $\mathrm{HCO}_{3}{ }^{-}$equivalents in the original sample. Solids were weighed and homogenized for $5 \mathrm{~s}$ using a tissue homogenizer (VWR PowerMax AHS 200, Pro Scientific, Oxford, CT), and then a similar procedure to base determination in fluids was followed, except $1 \mathrm{M} \mathrm{HCl}$ and $0.2 \mathrm{M} \mathrm{NaOH}$ were used.
Table 1

Juvenile alligator gar Atractosteus spatula mean ( \pm standard error) weights.

\begin{tabular}{lllr}
\hline Temperature $\left({ }^{\circ} \mathrm{C}\right)$ & Salinity $(\mathrm{ppt})$ & Source & \multicolumn{1}{c}{ Weight $(\mathrm{g})$} \\
\hline 10 & 0 & Inland & $116.31 \pm 16.99^{\mathrm{c}}$ \\
10 & 20 & Inland & $120.99 \pm 11.60^{\mathrm{c}}$ \\
30 & 0 & Inland & $52.90 \pm 4.97^{\mathrm{a}}$ \\
30 & 20 & Inland & $110.44 \pm 13.14^{\mathrm{bc}}$ \\
10 & 0 & Coastal & $61.02 \pm 7.25^{\mathrm{a}}$ \\
10 & 20 & Coastal & $80.56 \pm 6.10^{\mathrm{ab}}$ \\
30 & 0 & Coastal & $80.61 \pm 5.65^{\mathrm{ab}}$ \\
30 & 20 & Coastal & $59.24 \pm 10.65^{\mathrm{a}}$ \\
\hline
\end{tabular}

Lowercase superscript letters indicate significant differences between treatment groups, asterisks indicate significant differences between inland and coastal populations for a specific temperature and salinity combination (three-way analysis of variance; $p<0.05)$.

\subsection{NKA assay}

Gill tissue samples were thawed and $75 \mu \mathrm{L}$ of ice-cold SEI buffer was added containing $0.5 \%(\mathrm{w} / \mathrm{v})$ sodium deoxycholate for a final concentration of $0.1 \%$. Samples were immediately homogenized for 20-30 s, centrifuged at $5000 \times g$ for $1 \mathrm{~min}$ at $4{ }^{\circ} \mathrm{C}$ to remove large solids and kept on ice during the process. Supernatant was split into two $0.6 \mathrm{~mL}$ microcentrifuge tubes, one for protein measurement and one for NKA measurement, and then both were frozen in liquid nitrogen.

Protein concentration was determined in duplicate according to the bicinchoninic acid method by Smith et al. (1985) using a commercial assay kit $(23,227$, ThermoFisher Scientific, Waltham, MA, USA) in a microplate reader (SpectraMax M5, Molecular Devices, LLC, Sunnyvale, CA, USA). NKA activity was measured in duplicate following previous methods (Penefsky and Bruist, 1984; McCormick, 1993; Allen et al., 2009) that were verified for alligator gar (Schwarz and Allen, 2014).

\subsection{Statistical analysis}

Statistical values are reported as mean \pm standard error (SE). Data for body weight, plasma ion concentrations, osmolality and NKA were analyzed using three-way analyses of variance (ANOVA) with factors of population (inland and coastal), temperature $\left(10\right.$ and $\left.30{ }^{\circ} \mathrm{C}\right)$ and salinity (0 and $20 \mathrm{ppt}$ ) with four tank replicates per treatment combination (i.e., tanks as experimental units) and two fish subsamples per tank replicate using SAS statistical software version 9.4 (SAS Institute Inc., Cary, NC, USA). For three-way ANOVAs, treatment means were separated using the pdiff function in SAS. Gastrointestinal tract intestinal solid and dissolved solid base and $\mathrm{pH}$ were compared using two-way ANOVAs with factors of population and temperature, since only one salinity level was compared. Gastrointestinal tract intestinal fluid ions, base and $\mathrm{pH}$ were compared between populations of fish using student's $t$-tests adjusted with a Bonferroni correction. Stomach fluid data were not analyzed statistically due to lack of replication but were included to show trends between stomach and intestine since no data have been published on intestinal fluids in alligator gar. Normality and homogeneity of variance were tested by Shapiro-Wilk and Levene's tests, respectively. Data transformation (e.g., $\log _{10}$ ) was used when necessary to meet these ANOVA assumptions. If the overall ANOVA was significant, Tukey's honestly significant difference (HSD) test was used to compare treatment means. For all analyses, differences were considered significant at $P<0.05$, except for student's $t$-tests which were Bonferroni corrected.

\section{Results}

\subsection{Fish size, feeding and behavior}

Inland fish were generally larger than coastal fish, with the 


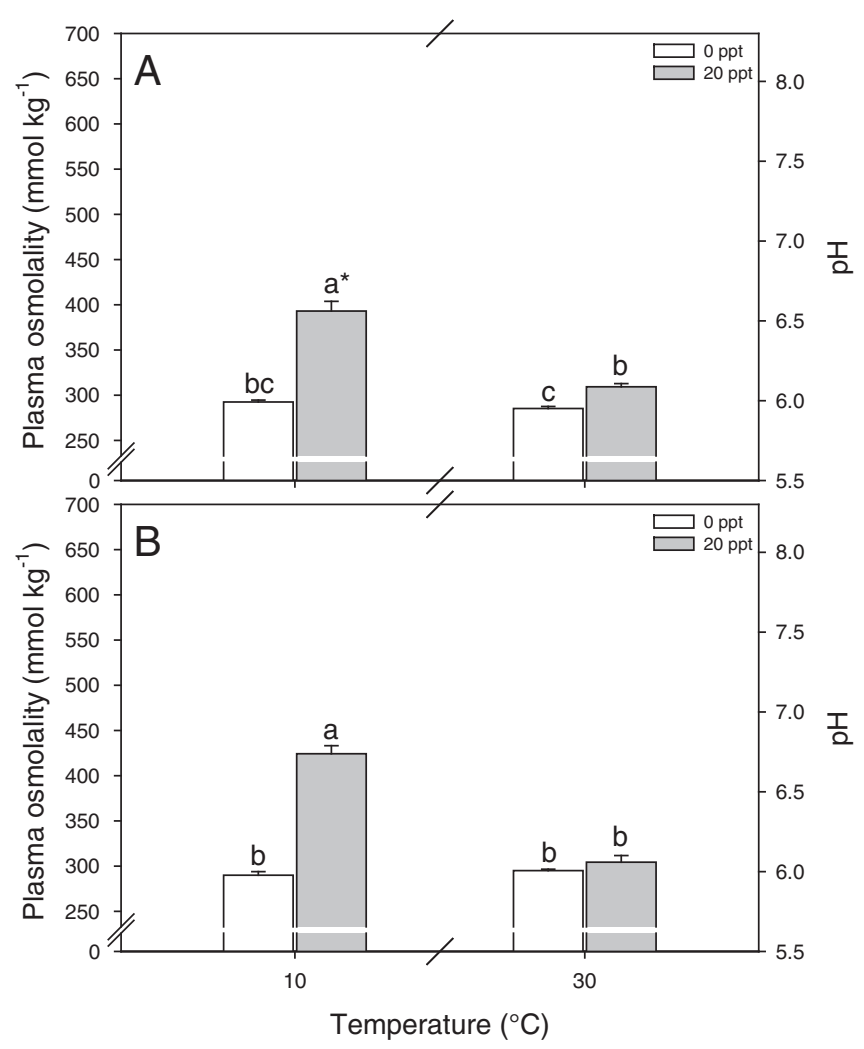

Fig. 1. Mean ( \pm standard error) plasma osmolality in (A) inland and (B) coastal populations of juvenile alligator gar (Atractosteus spatula) acclimated to different temperatures $\left(10\right.$ and $30{ }^{\circ} \mathrm{C}$ ) and salinities ( 0 and $20 \mathrm{ppt}$ ). Significant differences between treatment groups are denoted by a different lowercase letter (three-way analysis of variance; $p<0.05$ ).

exception of the $30{ }^{\circ} \mathrm{C}, 0$ ppt and $30^{\circ} \mathrm{C}, 20$ ppt treatments, where inland fish were smaller or similar in size to coastal fish (Table 1). Inland fish were similar in size except for the $30^{\circ} \mathrm{C}, 0$ ppt treatment which was smaller, and coastal fish were not different in weight among treatments (Table 1). High size variation is typical in juvenile alligator gar due in part to rapid growth rates and cannibalism (Mendoza Alfaro et al., 2008).

Fish in the low temperature treatments were lethargic. The $10{ }^{\circ} \mathrm{C}$, $20 \mathrm{ppt}$ treatment in particular, although not quantified, appeared to have slow opercular respiratory movements, did not appear to come to the surface for aerial respiration, were sluggish, tended to be unresponsive to stimuli, such as a nudge with a siphon, and occasionally appeared to lose equilibrium. Loss of equilibrium was indicated by leaning to one side.

\subsection{Blood plasma osmolality and ions}

Treatment water ion concentrations and osmolality were different between salinities (Table 2). For both populations of alligator gar, plasma osmolality was regulated at similar levels among different temperature and salinity treatments with the exception of low temperature $\left(10^{\circ} \mathrm{C}\right)$ and high salinity $(20 \mathrm{ppt})$ which had high osmolality values ( $\sim 35 \%$ higher; Fig. 1$)$. The $30^{\circ} \mathrm{C}, 20$ ppt treatment for inland fish was also slightly higher than the $30^{\circ} \mathrm{C}$, 0 ppt treatment in inland fish, and the $10^{\circ} \mathrm{C}, 0 \mathrm{ppt}$ treatment for both populations (Fig. 1).

For both populations, plasma ion concentrations followed similar patterns to plasma osmolality, with concentrations generally higher in the $10{ }^{\circ} \mathrm{C}, 20 \mathrm{ppt}$ treatment than other treatments (Fig. 2, Table 3). Comparing populations, plasma $\mathrm{Cl}^{-}$and $\mathrm{Na}^{+}$were higher $(\sim 10-15 \%)$ in the coastal population at $10^{\circ} \mathrm{C}, 20 \mathrm{ppt}$, but the relationships were very similar to other treatment groups (Fig. 2). Other plasma ions $\left(\mathrm{F}^{-}\right.$, 


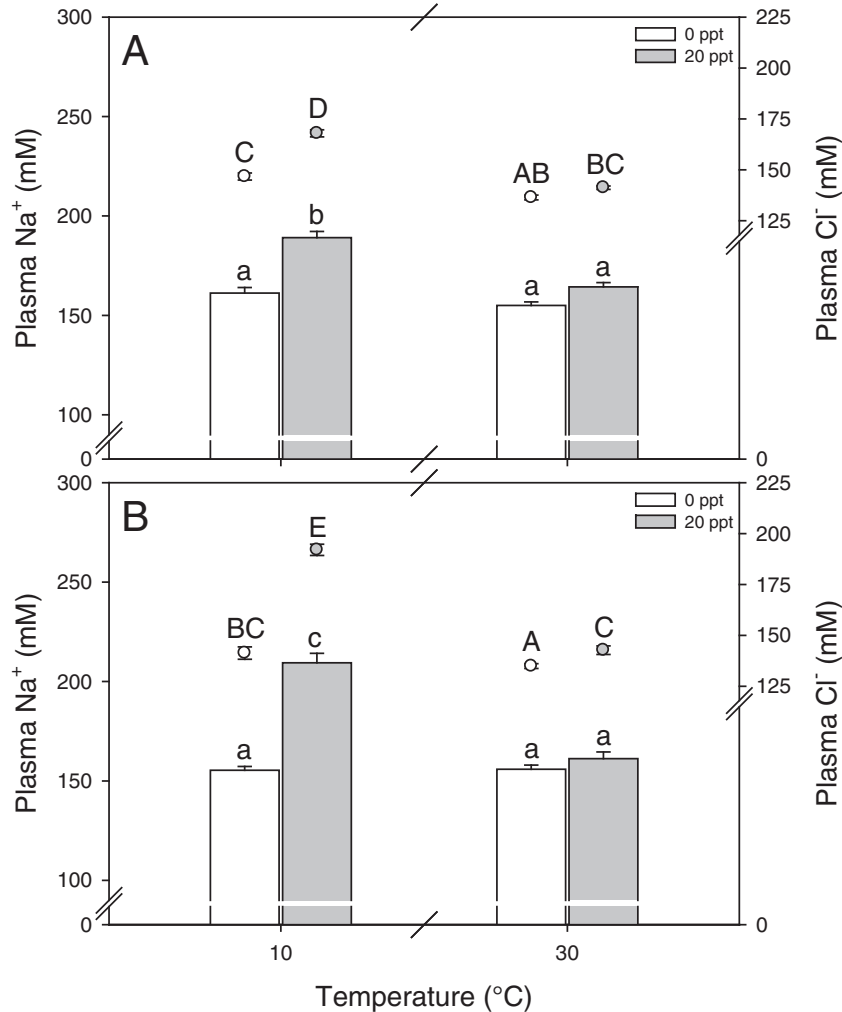

Fig. 2. Mean ( \pm standard error) plasma $\mathrm{Na}^{+}$and $\mathrm{Cl}^{-}$in (A) inland and (B) coastal populations of juvenile alligator gar (Atractosteus spatula) acclimated to different temperatures $\left(10\right.$ and $30^{\circ} \mathrm{C}$ ) and salinities $(0$ and $20 \mathrm{ppt}) . \mathrm{Na}^{+}$data are bars, $\mathrm{Cl}^{-}$data are circles. Significant differences between treatment groups are denoted by a different lowercase $\left(\mathrm{Na}^{+}\right)$or uppercase $\left(\mathrm{Cl}^{-}\right)$letter (three-way analysis of variance; $p<0.05$ ).

$\mathrm{Br}^{-}, \mathrm{PO}_{4}{ }^{3-}, \mathrm{SO}_{4}{ }^{2-}, \mathrm{K}^{+}, \mathrm{Mg}^{2+}$ and $\mathrm{Ca}^{2+}$ ) were not different among populations, however interactions among temperature $\times$ salinity were significant, therefore these relationships were evaluated (Table 3). For both populations, plasma $\mathrm{F}^{-}, \mathrm{SO}_{4}{ }^{2-}, \mathrm{K}^{+}$and $\mathrm{Ca}^{2+}$ were generally lower in the $10^{\circ} \mathrm{C}, 0 \mathrm{ppt}$ treatment than other treatments (Table 3). For both populations, the $10{ }^{\circ} \mathrm{C}, 20 \mathrm{ppt}$ treatment had higher plasma $\mathrm{Cl}^{-}$, $\mathrm{Br}^{-}, \mathrm{PO}_{4}{ }^{3-}, \mathrm{SO}_{4}{ }^{2-}, \mathrm{Na}^{+}, \mathrm{K}^{+}, \mathrm{Mg}^{2+}$, and $\mathrm{Ca}^{2+}$ than other treatments (most ions $15-35 \%$ higher, $\mathrm{Mg}^{2+}>3$-fold higher), and plasma $\mathrm{F}^{-}$ was higher than other treatments except for $30^{\circ} \mathrm{C}, 0 \mathrm{ppt}$ treatment (Fig. 2, Table 3). Plasma $\mathrm{NO}_{3}{ }^{-}$did not have a temperature $\times$salinity interaction, but the main effects of temperature $\left(10^{\circ} \mathrm{C}\right.$ : $\left.1.35 \pm 0.06 \mathrm{mM} ; 30{ }^{\circ} \mathrm{C}: 0.74 \pm 0.04 \mathrm{mM}, n=32 / \mathrm{trt}\right)$ and salinity (0 ppt: $0.91 \pm 0.07 \mathrm{mM} ; 20$ ppt: $1.18 \pm 0.07 \mathrm{mM}$ ) were significant.

\subsection{Gastrointestinal tract fluids and solids}

Fluids were only found in the gastrointestinal tract of fish in the $30{ }^{\circ} \mathrm{C}, 20 \mathrm{ppt}$ treatment from both populations. Only one fish had fluid in its stomach, all other fluids were in the intestinal region. Intestinal fluid ion concentrations were very similar between inland and coastal fish, with no statistical differences (Table 4). Calcium concentrations were unable to be obtained due to an instrumental error.

Titratable alkalinity $\left(\mathrm{HCO}_{3}{ }^{-}\right.$base, including $\mathrm{CO}_{2}$ and $\mathrm{CO}_{3}{ }^{2-}$ ) from gastrointestinal tract fluids, and intestinal fluid $\mathrm{pH}$ were very similar between populations, with no statistical differences (Table 5). In addition to the concentration of $\mathrm{HCO}_{3}{ }^{-}$, the total $\mathrm{HCO}_{3}{ }^{-}$derived from the volume of fluid in the intestine, was also similar between populations (Table 5).

Solids were found in the intestine of $10{ }^{\circ} \mathrm{C}, 20 \mathrm{ppt}$ and $30{ }^{\circ} \mathrm{C}, 20 \mathrm{ppt}$ treatments from both populations. Intestinal solids were colored browngreen, amorphous and jelly-like in fish in the $10^{\circ} \mathrm{C}, 20 \mathrm{ppt}$ treatment, and yellow-white and formed into a tube shape in fish in the $30^{\circ} \mathrm{C}$, 20 ppt treatment. Intestinal dissolved solids had similar $\mathrm{HCO}_{3}{ }^{-}$concentrations and $\mathrm{pH}$ between populations, with higher $\mathrm{HCO}_{3}{ }^{-}$concentrations and $\mathrm{pH}$ in the $30^{\circ} \mathrm{C}, 20 \mathrm{ppt}$ treatments than the $10^{\circ} \mathrm{C}, 20 \mathrm{ppt}$ treatments (Fig. 3). Similarly, both populations had greater total $\mathrm{HCO}_{3}{ }^{-}$ in intestinal dissolved solids in the $30^{\circ} \mathrm{C}, 20 \mathrm{ppt}$ treatments (inland: $9.60 \pm 3.41 \mu \mathrm{mol} \mathrm{\textrm {HCO } _ { 3 }}{ }^{-}$; coastal: $10.54 \pm 3.72 \mu{\mathrm{mol} \mathrm{HCO}_{3}}^{-}$) than the $10{ }^{\circ} \mathrm{C}, 20 \mathrm{ppt}$ treatments (inland: $0.63 \pm 0.36 \mathrm{~mol} \mathrm{HCO}_{3}{ }^{-}$; coastal: $-0.60 \pm 0.37 \mu \mathrm{mol} \mathrm{HCO}_{3}{ }^{-}$).

\subsection{NKA}

Gill NKA activities were not different among populations; however the relationship of temperature $*$ salinity was significant. Gill NKA was higher in the $10^{\circ} \mathrm{C}, 0 \mathrm{ppt}$ treatment than all other treatments, whereas all of the other treatments were similar (Fig. 4).

\section{Discussion}

The present study examined whether genetically differentiated populations of inland and coastal alligator gar differed in important functional physiological responses to extreme temperature and salinity environments. Environmental conditions were representative of extreme winter and summer conditions occurring in coastal and inland habitats within the distribution of alligator gar. Fish reared and acclimated in a common-garden environment were very similar in overall blood and gastrointestinal tract osmoregulatory parameters and gill NKA. In general, there were relatively few differences in blood plasma osmolality, ion concentrations, intestinal $\mathrm{pH}$ and bicarbonate base concentrations, intestinal fluid osmolality, ion concentrations and gill NKA between populations. Therefore, the hypothesis that coastal gar would have improved osmotic regulatory ability in saline environments as compared to inland alligator gar was not supported. Notably, gar from both populations did not osmoregulate well at low temperature and high salinity, with elevated plasma osmolality and ion concentrations, decreased plasma $\mathrm{pH}$, low gill NKA, and little evidence of gastrointestinal tract contribution to ionic and base regulation based on a lack of intestinal fluid and low base content.

Regulation of blood osmolality and ion concentrations is essential to occupancy of different salinity habitats. Both populations of gar regulated osmolality and ion concentrations effectively in low $\left(10^{\circ} \mathrm{C}\right)$ or high $\left(30{ }^{\circ} \mathrm{C}\right)$ temperatures in freshwater $(0 \mathrm{ppt})$ and at high temperatures in saline water $(20 \mathrm{ppt})$. Alligator gar are capable

Table 3

Mean ( \pm standard error) plasma ion concentrations in juvenile alligator gar Atractosteus spatula.

\begin{tabular}{|c|c|c|c|c|c|c|c|c|}
\hline Temp $\left({ }^{\circ} \mathrm{C}\right)$ & Salinity (ppt) & $\begin{array}{l}\mathrm{F}^{-} \\
(\mathrm{mM})\end{array}$ & $\begin{array}{l}\mathrm{Br}^{-} \\
(\mathrm{mM})\end{array}$ & $\begin{array}{l}\mathrm{PO}_{4}^{3-} \\
(\mathrm{mM})\end{array}$ & $\begin{array}{l}\mathrm{SO}_{4}{ }^{2-} \\
(\mathrm{mM})\end{array}$ & $\begin{array}{l}\mathrm{K}^{+} \\
(\mathrm{mM})\end{array}$ & $\begin{array}{l}\mathrm{Mg}^{2+} \\
(\mathrm{mM})\end{array}$ & $\begin{array}{l}\mathrm{Ca}^{2+} \\
(\mathrm{mM})\end{array}$ \\
\hline 10 & 0 & $0.97 \pm 0.11^{\mathrm{a}}$ & $0.36 \pm 0.01^{\mathrm{b}}$ & $2.04 \pm 0.26^{\mathrm{a}}$ & $0.64 \pm 0.04^{\mathrm{a}}$ & $4.87 \pm 0.55^{\mathrm{a}}$ & $1.10 \pm 0.04^{\mathrm{b}}$ & $2.78 \pm 0.05^{\mathrm{a}}$ \\
\hline 10 & 20 & $4.06 \pm 0.47^{c}$ & $0.45 \pm 0.02^{\mathrm{c}}$ & $3.63 \pm 0.33^{b}$ & $3.60 \pm 0.15^{\mathrm{d}}$ & $8.91 \pm 0.64^{c}$ & $3.78 \pm 0.10^{c}$ & $4.19 \pm 0.11^{\mathrm{c}}$ \\
\hline 30 & 0 & $3.46 \pm 0.22^{\mathrm{bc}}$ & $0.33 \pm 0.01^{\mathrm{a}}$ & $2.37 \pm 0.17^{\mathrm{a}}$ & $2.80 \pm 0.15^{c}$ & $5.93 \pm 0.28^{\mathrm{ab}}$ & $0.66 \pm 0.02^{\mathrm{a}}$ & $3.26 \pm 0.09^{b}$ \\
\hline 30 & 20 & $3.01 \pm 0.25^{\mathrm{b}}$ & $0.38 \pm 0.00^{\mathrm{b}}$ & $1.88 \pm 0.12^{\mathrm{a}}$ & $1.59 \pm 0.16^{\mathrm{b}}$ & $6.18 \pm 0.21^{\mathrm{b}}$ & $1.13 \pm 0.16^{\mathrm{b}}$ & $3.34 \pm 0.07^{\mathrm{b}}$ \\
\hline
\end{tabular}

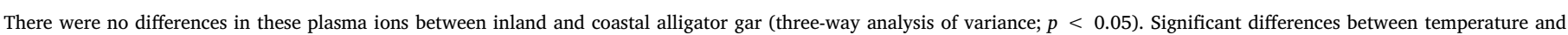
salinity treatments are indicated by lowercase letters. 
osmoregulators and can osmoregulate for prolonged periods of time in saline water (Schwarz and Allen, 2014). Plasma osmolality, $\mathrm{Na}^{+}$and $\mathrm{Cl}^{-}$were slightly elevated in coastal fish compared to inland fish in saline water at $10{ }^{\circ} \mathrm{C}$, possibly due to body size differences. Indeed, very few differences existed between populations in plasma ion concentrations. Body size differences between populations presumably influenced some of the small differences seen at $10{ }^{\circ} \mathrm{C}$ in saline water, with smaller sized treatments having slightly higher ion concentrations than larger sized treatment groups. Body size is known to be an important contributor to osmoregulatory ability in primitive fishes (Allen and Cech, 2007), with larger size conferring greater osmoregulatory ability presumably due to decreased gill surface area relative to internal body volume ratios, slowing internal ionic loss and uptake (Allen et al., 2009).

For both populations, osmoregulation was poor at low temperature $\left(10^{\circ} \mathrm{C}\right)$ and high salinity (20 ppt). Plasma osmolality and ion concentrations were increased in this treatment group compared to all other treatment groups, with $\mathrm{Na}^{+}$and $\mathrm{Cl}^{-}$showing the largest numerical changes and $\mathrm{Mg}^{2+}$ showing the largest relative change ( $>3$-fold increase). Relatively little is known of ionic regulatory abilities at cold temperatures in primitive fishes. In teleosts, osmo- and ionic regulation are less efficient or effective at low temperatures (Ahokas and Sorg, 1977; Handeland et al., 2008), with ions increasing in seawater and decreasing in freshwater (Stanley and Colby, 1971; Finstad et al., 1988; Gonzalez and McDonald, 2000; Sala-Rabanal et al., 2003). Loss of efficiency is presumably due to changes in membrane lipid structure and fluidity, restricting protein mobility (Hochachka and Somero, 2002). In support of the changes observed here, regulation of $\mathrm{Mg}^{2+}$ has been suggested to be more sensitive to low temperatures than $\mathrm{Na}^{+}$ and $\mathrm{Cl}^{-}$possibly due to changes in renal membrane-bound enzymatic salt extrusion processes (Finstad et al., 1988). Similarly, reduced efficiency of ionoregulatory processes at low temperatures was also observed in the low temperature $\left(10^{\circ} \mathrm{C}\right)$, low salinity $(0 \mathrm{ppt})$ treatment group through decreased plasma ions (i.e., $\mathrm{F}^{-}, \mathrm{SO}_{4}{ }^{2-}, \mathrm{K}^{+}$and $\mathrm{Ca}^{2+}$ ). Fish in the low temperature, high salinity treatment were observed to have a very slow rate of gill ventilation (although not quantified), and listless behavior near the tank bottoms, similar to behaviors observed in tilapia (Sun et al., 1995). Interestingly, extreme cold temperatures have been known to result in mortality in the Atlantic tarpon (Megalops atlanticus; Storey and Gudger, 1936; Overstreet, 1974), which occupies similar habitats and is also a partial air breather, similar to gars.

Important to the regulation of the primary monovalent ions $\mathrm{Na}^{+}$ and $\mathrm{Cl}^{-}$in seawater is the activity of gill NKA. Interestingly, gill NKA activity was nearly identical between populations. Although the higher salinity groups may have been expected to have higher NKA, this was not the case, similar to the findings of Schwarz and Allen (2014). Rather, the low temperature, low salinity treatment had over twice the NKA activity of the other treatment groups. In fishes, low temperatures have been associated with elevated gill NKA activity (Zaugg and McLain, 1976; Ventrella et al., 1993; Stuarnes et al., 1994) and elevated gene expression for ionoregulatory-related cells such as ionocytes (Chou et al., 2008). Low temperatures may slow rates of enzymatic reactions resulting in upregulation of total enzyme activity to compensate (Hochachka and Somero, 2002). The poor osmoregulatory ability of fish in the low temperature, high salinity treatment is likely due in part to the low gill NKA activity. Similarly, tilapia hybrids (Oreochromis mossambicus $\times$ O. urolepis hornorum) exposed to cool $\left(15^{\circ} \mathrm{C}\right)$, saline $(35 \mathrm{~g} / \mathrm{L})$ water have been shown to have increased mortality due to low gill NKA activity and increased plasma $\mathrm{Na}^{+}, \mathrm{Cl}^{-}$and osmolality (Sardella et al., 2004). In contrast to the gills, gastrointestinal tract NKA activity has been shown to increase in hyperosmotic salinities in alligator gar, due to drinking (Schwarz and Allen, 2014).

In addition to blood, gastrointestinal tract osmolality, ion regulation and $\mathrm{HCO}_{3}{ }^{-}$base were regulated similarly between populations. Alligator gar drink in hyperosmotic salinities (Schwarz and Allen, 2014) to prevent dehydration, and in this study, fluids were only found 
Table 5

Mean ( \pm standard error) $\mathrm{HCO}_{3}{ }^{-} / \mathrm{CO}_{3}{ }^{2-}$ in the gastrointestinal tract fluids of juvenile alligator gar Atractosteus spatula.

\begin{tabular}{|c|c|c|c|c|c|c|}
\hline $\begin{array}{l}\text { Temp } \\
\left({ }^{\circ} \mathrm{C}\right)\end{array}$ & $\begin{array}{l}\text { Salinity } \\
\text { (ppt) }\end{array}$ & Source & GIT region & $\mathrm{pH}$ & $\begin{array}{l}\mathrm{HCO}_{3}{ }^{-} \\
\left(\mathrm{mmol} \mathrm{kg}{ }^{-1}\right)\end{array}$ & $\begin{array}{l}\text { Total } \mathrm{HCO}_{3}^{-} \\
(\mu \mathrm{mol})\end{array}$ \\
\hline 30 & 20 & Inland & Stom & 6.95 & 2.80 & 0.59 \\
\hline 30 & 20 & Inland & Int & $7.92 \pm 0.05$ & $22.73 \pm 1.46$ & $2.01 \pm 0.32$ \\
\hline 30 & 20 & Coastal & Int & $7.80 \pm 0.13$ & $18.84 \pm 4.21$ & $2.07 \pm 1.20$ \\
\hline
\end{tabular}

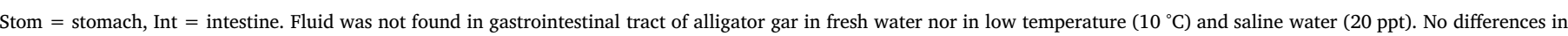

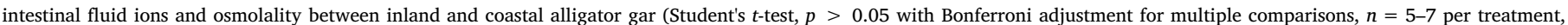
except for stomach where $n=1$ ).

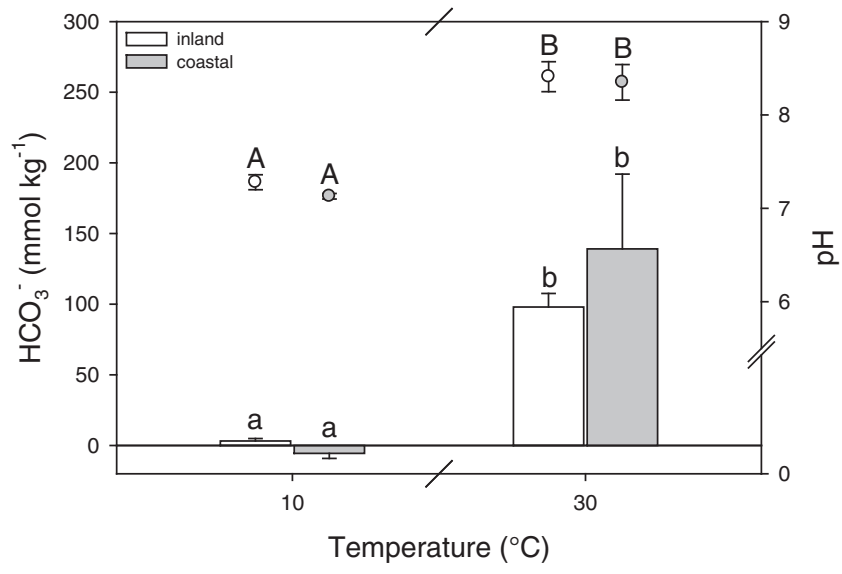

Fig. 3. Mean ( \pm standard error) intestinal dissolved solid $\mathrm{HCO}_{3}{ }^{-}$concentrations and $\mathrm{pH}$ in juvenile alligator gar (Atractosteus spatula) acclimated to different temperatures (10 and $30{ }^{\circ} \mathrm{C}$ ) at a salinity of $20 \mathrm{ppt} . \mathrm{HCO}_{3}{ }^{-}$data are bars, $\mathrm{pH}$ data are circles. Significant differences between treatment groups are denoted by a different lowercase letter for $\mathrm{HCO}_{3}{ }^{-}$and uppercase letter for $\mathrm{pH}$ (two-way analysis of variance, Tukey's HSD post hoc test, $p<0.05$ ). There were no differences between populations.

in the stomach and intestine in high temperature $\left(30^{\circ} \mathrm{C}\right)$ and high salinity (20 ppt). Solids were found in this same treatment, and also at the low temperature $\left(10^{\circ} \mathrm{C}\right)$ and high salinity treatment, albeit with different consistency, color and base content. Mucus tube solids (Shehadeh and Gordon, 1969) are well known from anadromous and marine teleosts (Wilson et al., 1996, 2002; Grosell, 2006) and primitive fishes (Taylor and Grosell, 2006; Allen et al., 2009). Mucus solids are formed as a result of drinking and absorption of $\mathrm{Cl}^{-}$in exchange for $\mathrm{HCO}_{3}{ }^{-}$in the anterior intestine and pyloric caeca. In the intestinal lumen, $\mathrm{Na}^{+}$enters the apical membrane of enterocytes down an electrochemical gradient via $\mathrm{Na}^{+} / \mathrm{Cl}^{-}$and $\mathrm{Na}^{+} / \mathrm{K}^{+} / 2 \mathrm{Cl}^{-}$co-transporters and exits via NKA (Grosell, 2011). $\mathrm{Cl}^{-}$enters enterocytes against an electrochemical gradient via $\mathrm{Na}^{+} / \mathrm{Cl}^{-}$and $\mathrm{Na}^{+} / \mathrm{K}^{+} / 2 \mathrm{Cl}^{-}$cotransporters and also via $\mathrm{Na}^{+}$-independent pathways such as the aforementioned $\mathrm{Cl}^{-} / \mathrm{HCO}_{3}{ }^{-}$exchangers, and exits the basolateral membrane via $\mathrm{Cl}^{-}$channels (Grosell, 2011). Water osmotically follows $\mathrm{Na}^{+}$and $\mathrm{Cl}^{-}$. The $\mathrm{HCO}_{3}^{-}$base excreted into the intestine combines primarily with $\mathrm{Ca}^{2+}$ in the intestine forming a solid and precipitating out of solution (Wilson et al., 2002; Wilson and Grosell, 2003). The solids are coated to some extent with mucus stained by bile and tend to have a tube shape, with white to yellow coloration (Shehadeh and Gordon, 1969). In this study, the solids in the high temperature and high salinity were of this shape and color with high base content, and are the first documented evidence of mucus tubes in hyperosmotic environments in the gars. In contrast, the solids in the low temperature and high salinity treatments were generally amorphous, jelly-like and greenish in color. When considered with the lack of intestinal fluids and the lower $\mathrm{pH}$, it appears that fish were not drinking at the same rate in this treatment, and the gastrointestinal tract was not being used to excrete base.

Lack of divergence in physiological capacity for osmoregulation
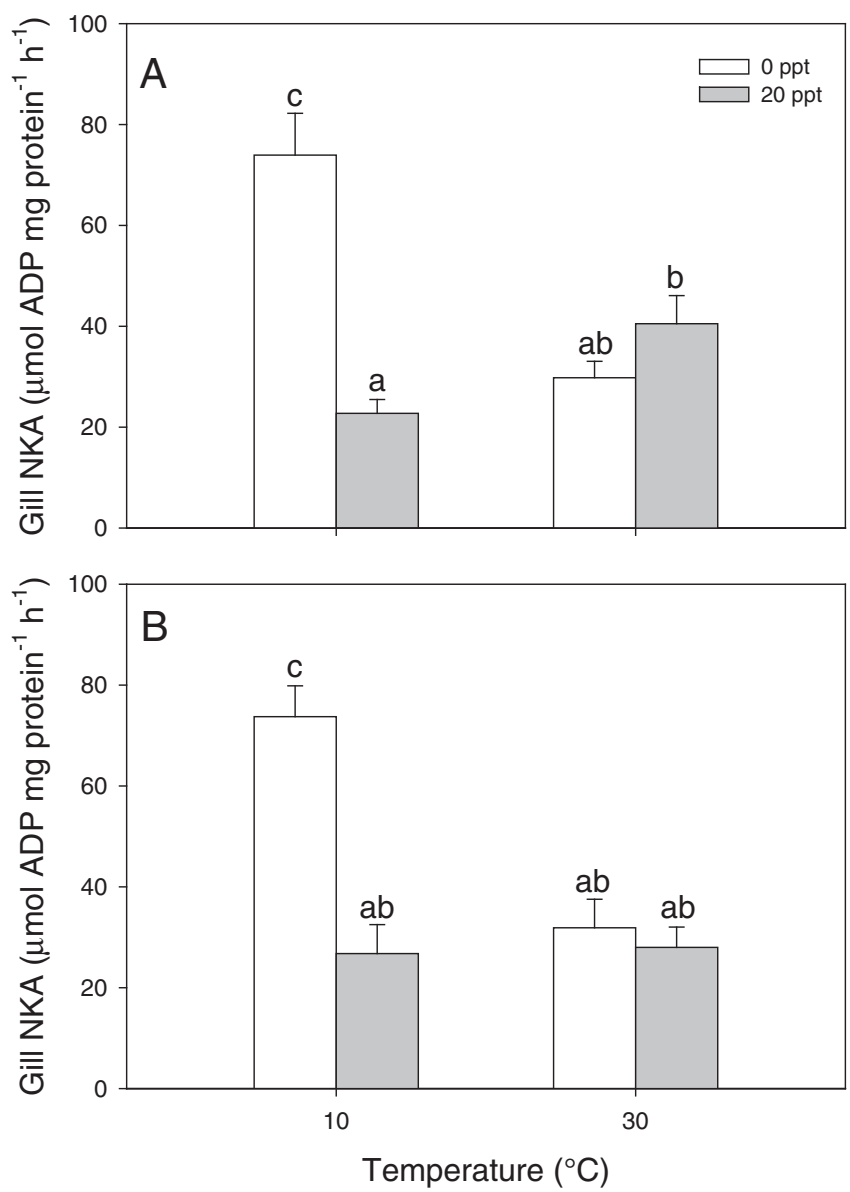

Fig. 4. Mean ( \pm standard error) gill $\mathrm{Na}^{+}, \mathrm{K}^{+}$-ATPase activities (NKA) in juvenile alligator gar (Atractosteus spatula) acclimated to different temperatures $\left(10\right.$ and $\left.30{ }^{\circ} \mathrm{C}\right)$ and salinities ( 0 and $20 \mathrm{ppt}$ ). Significant differences between treatment groups are denoted by a different lowercase letter (three-way analysis of variance; $p<0.05$ ). There were no differences between populations.

between inland and coastal alligator gar may be due to niche conservatism (reviewed by Wiens et al., 2010), or alternatively to recent genetic divergence and insufficient time for genetic drift, or slow genetic drift due to low variability in this trait within the population (Reznick et al., 1997). Alligator gar and other neopterygians are estimated to have diverged in a radiative event approximately 284 million years ago (Hurley et al., 2007). Wright et al. (2012) noted that the gars were a formerly numerous and widespread group but apparently exist as "living fossils" with little change through long evolutionary time periods, challenging paradigms of continued change and adaptation to local environments. The timeframe for genetic divergence of inland and coastal populations is difficult to estimate for alligator gar, due to uncertainty in past environmental events and the numerous factors that may affect divergence (Gavrilets and Losos, 2009). Phenotypic differences in fish populations may occur over very small time 
scales on the order of decades in response to founder populations (Reznick et al., 1997; Hendry et al., 2000) but genetic divergence presumably takes far longer. African cichlids and northern hemisphere sticklebacks (Gasterosteus sp.) are well known for their rapid evolutionary divergence where speciation has occurred in several radiations over the past 12,000 years (Danley and Kocher, 2001; Reusch et al., 2001). For most primitive fishes, there is little information on extant species with recent adaptation to local environments. Similar to the results of this study, a recent study on alligator gar found no differences in temperature tolerance between three inland and coastal populations over a latitudinal gradient, and no evidence of local adaptation (Fernando et al., 2016).

Does maintenance of osmoregulatory capacity provide an advantage even if movement to saline water does not occur? Although landlocked populations of Arctic char (Salvelinus alpinus) have been shown to have reduced osmoregulatory ability (Bystriansky et al., 2007), similar salinity tolerance persists compared to anadromous fish in some populations (Schmitz, 1995). For Atlantic salmon (Salmo salar), nonmigratory and migratory populations have been shown to retain similar gene function related to salinity tolerance (Lemmetyinen et al., 2013), similar gill NKA and osmoregulatory abilities (Piironen et al., 2013) and similar salinity tolerance (Schmitz, 1995). Piironen et al. (2013) and Lemmetyinen et al. (2013) suggest retaining these traits may continue to provide an adaptive advantage by cueing seasonal migration from low-productivity river habitats to higher productivity lake habitats. Alligator gar however, are not landlocked and apparently do not migrate long-distances (Buckmeier et al., 2013). Therefore, the advantage of retaining these traits is less certain. In a primitive fish such as alligator gar, perhaps it has as much to do with their past as their present. It may be these traits have facilitated their persistence through past environmental variability. It is also possible that relatively shortterm movement studies do not capture aberrations that may occur over a longer time period, although genetic divergence between inland and coastal populations supports limited mating between populations.

In conclusion, osmo- and ionic regulation were very similar between inland and coastal alligator gar populations over a wide range of temperature and salinity environments. Small differences were observed in a few parameters, likely due to body size differences. Although the two populations are known to be genetically distinct, divergence in physiological function of osmoregulation was not observed. The two populations are not separated by physical barriers, and in a long-lived, primitive species such as alligator gar, the retention of important physiological functional genes may relate to past environmental change and ensure long-term species survival, suggesting the importance of niche conservatism.

\section{Acknowledgements}

We thank Chris Green at the Louisiana State University AgCenter, Baton Rouge, LA, USA and Ricky Campbell and staff at the US Fish and Wildlife Service Private John Allen National Fish Hatchery, Tupelo, MS, USA for providing juvenile alligator gar; Alichia Wilson, Anthony Fernando, Kyle Rachels for assistance in sampling; the Mississippi Agricultural and Forestry Experiment Station (MAFES) and the US Department of Agriculture (USDA) Agricultural Research Service for facility support; and two anonymous reviewers for helpful comments in the review of this manuscript. This material is based upon work supported by the USDA National Institute of Food and Agriculture, State project\#: 1005154.

\section{References}

Ahokas, R.A., Sorg, G., 1977. The effect of salinity and temperature on intracellular osmoregulation and muscle free amino acids in Fundulus diaphanus. Comp. Biochem. Physiol. A 56, 101-105.

Allen, P.J., Cech Jr., J.J., 2007. Age/size effects on juvenile green sturgeon, Acipenser medirostris, oxygen consumption, growth, and osmoregulation in saline environments. Environ. Biol. Fish 79, 211-229.

Allen, P.J., Cech, J.J., Kültz, D., 2009. Mechanisms of seawater acclimation in a primitive, anadromous fish, the green sturgeon. J. Comp. Physiol. B. 179, 903-920.

Allen, P.J., McEnroe, M., Forostyan, T., Cole, S., Nicholl, M.M., Hodge, B., Cech Jr., J.J., 2011. Ontogeny of salinity tolerance and evidence for seawater-entry preparation in juvenile green sturgeon, Acipenser medirostris. J. Comp. Physiol. B. 181, 1045-1062.

Aykanat, T., Thrower, F.P., Heath, D.D., 2011. Rapid evolution of osmoregulatory function by modification of gene transcription in steelhead trout. Genetica 139, $233-242$.

Beamish, F.W.H., 1980. Osmoregulation in juvenile and adult lampreys. Can. J. Fish. Aquat. Sci. 37, 1739.

Beamish, F.W.H., Strachan, P.D., Thomas, E., 1978. Osmotic and ionic performance of the anadromous sea lamprey Petromyzon marinus. Comp. Biochem. Physiol. A 60, 435-444.

Bekkevold, D., Andre, C., Dahlgren, T.G., Clausen, L.A.W., Torstensen, E., Mosegaard, H., Carvalho, G.R., Christensen, T.B., Norlinder, E., Ruzzante, D.E., 2005. Environmental correlates of population differentiation in Atlantic herring. Evolution 59, 2656-2668.

Bohn, S.E., 2013. Conservation Genetics of gar (Atractosteus spp.). University of Southern Mississippi (88 pgs.).

Bozinovic, F., Calosi, P., Spicer, J.I., 2011. Physiological correlates of geographic range in animals. Ann. Rev. Ecol. Evol. Syst. 42, 155-179.

Bridle, J.R., Vines, T.H., 2006. Limits to evolution at range margins: when and why does adaptation fail? Trends Ecol. Evol. 22, 140-147.

Buckmeier, D.L., Smith, N.G., Reeves, K.S., 2012. Utility of alligator gar age estimates from otoliths, pectoral fin rays, and scales. Trans. Am. Fish. Soc. 141 (6), 1510-1519.

Buckmeier, D.L., Smith, N.G., Daugherty, D.J., 2013. Alligator gar movement and macrohabitat use in the lower Trinity River, Texas. Trans. Am. Fish. Soc. 142, 1025-1035.

Bystriansky, J.S., Frick, N.T., Richards, J.G., Schulte, P.M., Ballantyne, J.S., 2007. Failure to up-regulate gill $\mathrm{Na}^{+}, \mathrm{K}^{+}$-ATPAse a-subunit isoform a1b may limit seawater tolerance of land-locked Arctic char (Salvelinus alpinus). Comp. Biochem. Physiol. A 148, 332-338.

Cavin, L., 2010. Diversity of Mesozoic semionotiform fishes and the origin of gars (Lepisosteidae). Naturwissenschaften 97, 1035-1040.

Chou, M.Y., Hsiao, C.D., Chen, S.C., Chen, I.W., Liu, S.T., Hwang, P.P., 2008. Effects of hypothermia on gene expression in zebrafish gills: upregulation in differentiation and function of ionocytes as compensatory responses. J. Exp. Biol. 211, 3077-3084.

Danley, P.D., Kocher, T.D., 2001. Speciation in rapidly diverging systems: lessons from Lake Malawi. Mol. Ecol. 10, 1075-1086.

DeFaveri, J., Shikano, T., Shimada, Y., Goto, A., Merila, J., 2011. Global analysis of genes involved in freshwater adaptation in threespine sticklebacks (Gasterosteus aculeatus). Evolution 65-6, 1800-1807.

DiBenedetto, K., 2009. Life History Characteristics of Alligator gar Atractosteus spatula in the Bayou Dularge Area of Southcentral Louisiana. Louisiana State University, Baton Rouge, LA (59 pgs.).

Fernando, A.V., Lochmann, S.E., Haukenes, A.H., 2016. Critical thermal maxima of juvenile alligator gar (Atractosteus spatula, Lacepede, 1803) from three Mississippidrainage populations acclimated to three temperatures. J. Appl. Ichthyol. 32, 701-705.

Ferrara, A.M., 2001. Life-History Strategy of Lepisosteidae: Implications for the Conservation and Management of Alligator gar. Department of Fisheries and Allied Aquacultures. Auburn University (126 pgs.).

Finstad, B., Staurnes, M., Reite, O.B., 1988. Effect of low temperature on sea-water tolerance of rainbow trout, Salmo gairdneri. Aquaculture 72, 319-328.

Gavrilets, S., Losos, J.B., 2009. Adaptive radiation: contrasting theory with data. Science $323,732-737$.

Gonzalez, R.J., McDonald, D.G., 2000. Ionoregulatory responses to temperature change in two species of freshwater fish. Fish Physiol. Biochem. 22, 311-317.

Goodyear, C.P., 1967. Feeding habits of three species of gars, Lepisosteus, along the Mississippi Gulf Coast. Trans. Am. Fish. Soc. 96, 297-300.

Griffith, R.W., 1974. Environment and salinity tolerance in the genus Fundulus. Copeia 1974, 319-331.

Grosell, M., 2006. Intestinal anion exchange in marine fish osmoregulation. J. Exp. Biol. 209, 2813-2827.

Grosell, M., 2011. The role of the gastrointestinal tract in salt and water balance. In: Grosell, M., Farrell, A.P., Brauner, C.J. (Eds.), The Multifunctional gut of Fish. Fish Physiology, vol. 30. Academic Press, San Diego, CA, USA, pp. 135-164.

Handeland, S.O., Imsland, A.K., Stefansson, S.O., 2008. The effect of temperature and fish size on growth, feed intake, food conversion efficiency and stomach evacuation rate of Atlantic salmon post-smolts. Aquaculture 283, 36-42.

Hendry, A.P., Wenburg, J.K., Bentzen, P., Volk, E.C., Quinn, T.P., 2000. Rapid evolution of reproductive isolation in the wild: evidence from introduced salmon. Science 290 , 516-518.

Hochachka, P.W., Somero, G.N., 2002. Biochemical Adaptation: Mechanism and Process in Physiological Evolution. Oxford University Press, New York (466 pgs.).

Hurley, I.A., Mueller, R.L., Dunn, K.A., Schmidt, E.J., Friedman, M., Ho, R.K., Prince, V.E. Yang, Z., Thomas, M.G., Coates, M.I., 2007. A new time-scale for ray-finned fish evolution. Proc. R. Soc. B 274, 489-498.

Hutchinson, G.E., 1957. Concluding remarks. Population studies: animal ecology and demography. Cold Spring Harb. Symp. Quant. Biol. 22, 415-427.

Kluender, E.R., Adams, R., Lewis, L., 2016. Seasonal habitat use of alligator gar in a riverfloodplain ecosystem at multiple spatial scales. Ecol. Freshw. Fish. http://dx.doi.org/ 10.1111/eff.12270. (14 pgs.).

Koehn, R.K., Newell, R.I.E., Immermann, F., 1980. Maintenance of an aminopeptidase allele frequency cline by natural selection. Proc. Natl. Acad. Sci. 77, 5385-5389. 
Le Bras, Y., Dechamp, N., Krieg, F., Filangi, O., Guyomard, R., Boussaha, M., Bovenhuis, H., Pottinger, T.G., Prunet, P., Le Roy, P., Quillet, E., 2011. Detection of QTL with effects on osmoregulation capacities in the rainbow trout (Oncorhynchus mykiss). BMC Genet. 12, 46.

Lemmetyinen, J., Piironen, J., Kiiskinen, P., Hassinen, M., Voranen, M., 2013. Comparison of gene expression in the gill of salmon (Salmo salar) smolts from anadromous and landlocked populations. Ann. Zool. Fenn. 50, 16-35.

Lenormand, T., 2002. Gene flow and the limits to natural selection. Trends Ecol. Evol. 17, 183-189.

McCormick, S.D., 1993. Methods for nonlethal gill biopsy and measurement of $\mathrm{Na}^{+}, \mathrm{K}^{+}$ATPase activity. Can. J. Fish. Aquat. Sci. 50, 656-658.

McCormick, S.D., 1994. Ontogeny and evolution of salinity tolerance in anadromous salmonids: hormones and heterochrony. Estuaries 17, 26-33.

McDowall, R.M., 1988. Diadromy in Fishes. Timber Press, Portland.

McDowall, R.M., 1997. The evolution of diadromy in fishes (revisited) and its place in phylogenetic analysis. Rev. Fish Biol. Fish. 7, 443-462.

McGrath, P.E., Hilton, E.J., Musick, J.A., 2012. Seasonal distributions and movements of longnose gar (Lepisosteus osseus) within the York River System, Virginia. Southeast. Nat. 11, 375-386.

Mendoza Alfaro, R., Gonzalez, C.A., Ferrara, A.M., 2008. Gar biology and culture: status and prospects. Aquac. Res. 39, 748-763.

Moyer, G.R., Sloss, B.L., Kreiser, B.R., Feldheim, K.A., 2009. Isolation and characterization of microsatellite loci for alligator gar (Atractosteus spatula) and their variability in two other species (Lepisosteus oculatus and L. osseus) of Lepisosteidae. Mol. Ecol. Resour. 9, 963-966.

Nichols, K.M., Edo, A.F., Wheeler, P.A., Thorgaard, G.H., 2008. The genetic basis of smoltification-related traits in Oncorhynchus mykiss. Genetics 179, 1559-1575.

Nickum, J.G., Bart, H.L., Bowser, P.R., Greer, I.E., Hubbs, C., Jenkins, J.A., MacMillan, J.R., Rachlin, J.W., Rose, J.D., Sorensen, P.W., Tomasso, J.R., 2004. Guidelines for the use of Fishes in Research. American Fisheries Society. http://fisheries.org/docs/ policy_useoffishes.pdf.

NOAA, 2015. (National Oceanic and Atmospheric Administration). National Centers for environmental information. Water data of the eastern and western Gulf of Mexico. Available. https://www.nodc.noaa.gov/dsdt/cwtg/egof.html (December 2015).

Norman, J.D., Danzmann, R.G., Glebe, B., Ferguson, M.M., 2011. The genetic basis of salinity tolernace traits in Arctic charr (Salvelinus alpinus). BMC Genomics 12, 81.

Overstreet, R.M., 1974. An estuarine low temperature fish kill in Mississippi, with remarks on restricted necropsies. Gulf Coast Res. Rep. 4, 328-350.

Penefsky, H.S., Bruist, M.F., 1984. Adenosinetriphosphatases. In: Bergmeyer, H.U., Bergmeyer, J., Grabl, M. (Eds.), Methods of Enzymatic Analysis, third ed. Weinheim, Verlag Chemie, pp. 324-335.

Piironen, J., Kiiskinen, P., Huuskonen, H., Heikura-Ovaskainen, M., Vornanen, M., 2013. Comparison of smoltification in Atlantic salmon (Salmo salar) from anadromous and landlocked populations under common garden conditions. Ann. Zool. Fenn. 50, 1-15.

Pörtner, H.O., Knust, R., 2007. Climate change affects marine fishes through the oxygen limitation of thermal tolerance. Science 315, 95-97.

Purcell, K.M., Hitch, A.T., Klerks, P.L., Leberg, P.L., 2008. Adaptation as a potential response to sea-level rise: a genetic basis for salnity tolerance in populations of a coastal marsh fish. Evol. Appl. 1, 155-160.

Reusch, T.B.H., Wegner, K.M., Kalbe, M., 2001. Rapid genetic divergence in postglacial populations ofthreespine stickleback (Gasterosteus aculeatus): the role of habitat type, drainage and geographical proximity. Mol. Ecol. 10, 2435-2445.

Reznick, D.N., Shaw, F.H., Rodd, F.H., Shaw, R.G., 1997. Evaluaton of the rate of evolution in natural populations of guppies (Poecilia reticulata). Science 275, 1934-1937.

Richards, J.E., Beamish, F.W.H., 1981. Initiation of feeding and salinity tolerance in the Pacific lamprey Lampetra tridentata. Mar. Biol. 63, 73-77.

Ross, S.T., 2001. The Inland Fishes of Mississippi. University Press of Mississippi (624 pgs.).

Sakaris, P.C., Ferrara, A.M., Kleiner, K.J., Irwin, E.R., 2003. Movements and Home Ranges of Alligator gar in the Mobile-Tensaw Delta, Alabama. Proc. Ann. Conf. Southeastern Assoc. Fish Wild. Agenc Vol. 57. pp. 102-111.

Sala-Rabanal, M., Sanchez, J., Ibarz, A., Fernandez-Borras, J., Blasco, J., Gallardo, M.A., 2003. Effects of low temperatures and fasting on hematology and plasma composition of gilthead sea bream (Sparus aurata). Fish Physiol. Biochem. 29, 105-115.

Sardella, B.A., Cooper, J., Gonzalez, R.J., Brauner, C.J., 2004. The effect of temperature on juvenile Mozambique tilapia hybrids (Oreochromis mossambicus $\times$ O. urolepis hornorum) exposed to full-strength and hypersaline seawater. Comp. Biochem. Physiol. A 137, 621-629.

Schmitz, M., 1995. Seasonal changes in hypoosmoregulatory ability in landlocked and anadromous populations of Arctic charr, Salvelinus alpinus, and Atlantic salmon,
Salmo salar. Environ. Biol. Fish 42, 401-412.

Schwarz, D.E., Allen, P.J., 2014. Effects of salinity on growth and ion regulation of juvenile alligator gar Atractosteus spatula. Comp. Biochem. Physiol. A 169, 44-50.

Shehadeh, Z.H., Gordon, M.S., 1969. The role of the intestine in salinity adaptation of the rainbow trout, Salmo gairdneri. Comp. Biochem. Physiol. 30, 397-418.

Smatresk, N.J., Cameron, J.N., 1982. Respiration and acid-base physiology of the spotted gar, a bimodal breather. III. Response to a transfer from fresh water to $50 \%$ sea water, and control of ventilation. J. Exp. Biol. 96, 295-306.

Smith, P.K., Krohn, R.I., Hermanson, G.T., Mallia, A.K., Gartner, F.H., Provenzano, M.D., Fujimoto, E.K., Goeke, N.M., Olson, B.J., Klenk, D.C., 1985. Measurements of protein using bicinchoninic acid. Anal. Biochem. 150, 76-85.

Somero, G.N., 2005. Linking biogeography to physiology: evolutionary and acclimatory adjustments of thermal limits. Front. Zool. 2, 1.

Stanley, J.G., Colby, P.J., 1971. Effects of temperature on electrolyte balance and osmoregulation in the alewife (Alosa pseudoharengus) in fresh and sea water. Trans. Am. Fish. Soc. 100, 624-638.

Storey, M., Gudger, E.W., 1936. Mortality of fishes due to cold at Sanibel Island, Florida, 1886-1936. Ecology 17, 640-648.

Stuarnes, M., Rainuzzo, J.R., Sigholt, T., Jogensen, L., 1994. Acclimation of Atlantic cod (Gadus morhua) to cold water: stress response, osmoregulation, gill lipid composition and gill Na-K-ATPase activity. Comp. Biochem. Physiol. A 109, 413-421.

Suchy, M.D., 2009. Effects of Salinity on Growth and Survival of Larval and Juvenile Alligator gar Atractosteus spatula, and on Plasma Osmolality of non-teleost Actinopterygiian Fishes. Biology Dept. Nicholls State University, Thibodaux, LA, pp. 96.

Sun, L.-T., Chen, G.-R., Chang, C.-F., 1995. Acute responses of blood parameters and comatose effects in salt-acclimated tilapias exposed to low temperatures. J. Therm. Biol. 20, 299-306.

Suttkus, R.D., 1963. Order Lepisostei. In: Memoir, Sears Foundation of Marine Research. Vol. 1, pt. 3. Yale University, New Haven, Conn, pp. 61-88.

Taylor, J.R., Grosell, M., 2006. Evolutionary aspects of intestinal bicarbonate secretion in fish. Comp. Biochem. Physiol. A 143, 523-529.

Thomas, C.D., Bodsworth, E.J., Wilson, R.J., Simmons, A.D., Davies, Z.G., Musche, M., Conradt, L., 2001. Ecological and evolutionary processes at expanding range margins. Nature 411, 577-581.

USGS, 2015. U.S. Geological Survey. In: Mississippi River Temperature Data, Available: http://nwis.waterdata.usgs.gov/usa/nwis.

Ventrella, V., Pagliarani, A., Pirini, M., Trigari, G., Trombetti, F., Borgatti, A.R., 1993. Lipid composition and microsomal ATPase activities in gills and kidneys of warmand cold-acclimated sea bass (Dicentrarchus labrax L.). Fish Physiol. Biochem. 12, 293-304.

Vieites, D.R., Nieto-Roman, S., Wake, D.B., 2009. Reconstruction of the climate envelopes of salamanders and their evolution through time. Proc. Natl. Acad. Sci. 106, 19715-19722.

Wiens, J.J., Graham, C.H., 2005. Niche conservatism: integrating evolution, ecology, and conservation biology. Ann. Rev. Ecol. Evol. Syst. 36, 519-539.

Wiens, J.J., Ackerly, D.D., Allen, A.P., Anacker, B.L., Buckley, L.B., Cornell, H.V., Damschen, E.I., Davies, T.J., Grytnes, J.A., Harrison, S.P., Hawkins, B.A., Holt, R.D., McCain, C.M., Stephens, P.R., 2010. Niche conservatism as an emerging principle in ecology and conservation biology. Ecol. Lett. 13, 1310-1324.

Wiley, E.O., 1976. The phylogeny and biogeography of fossil and recent gars (Actinopterygii: Lepisosteidae). In: The University of Kansas Museum of Natural History, Miscellaneous Publication No. 64, pp. 111.

Wiley, E.O., Schultze, H.P., 1984. Family Lepisosteidae (gars) as living fossils. In: Eldredge, N. (Ed.), Living fossils. Springer-Verlag, Inc., New York, pp. 160-165.

Wilson, R.W., Grosell, M., 2003. Intestinal bicarbonate secretion in marine teleost fish-source of bicarbonate, $\mathrm{pH}$ sensitivity, and consequences for whole animal acidbase and calcium homeostasis. Biochim. Biophys. Acta Biomembr. 1618, 163-174.

Wilson, R.W., Gilmour, K.M., Henry, R.P., Wood, C.M., 1996. Intestinal base excretion in the seawater-adapted rainbow trout: a role in acid-base balance? J. Exp. Biol. 199, 2331-2343.

Wilson, R.W., Wilson, J.M., Grosell, M., 2002. Intestinal bicarbonate secretion by marine teleost fish - why and how? Biochim. Biophys. Acta Biomembr. 1566, 182-193.

Wright, J.J., David, S.R., Near, T.J., 2012. Gene trees, species trees, and morphology converge on a similar phylogeny of living gars (Actinopterygii: Holostei: Lepisosteidae), an ancient clade of ray-finned fishes. Mol. Phylogenet. Evol. 63, 848-856.

Zaugg, W.S., McLain, L.R., 1976. Influence of water temperature on gill sodium, potassium-stimulated ATPase activity in juvenile coho salmon (Oncorhynchus kisutch). Comp. Biochem. Physiol. A 54, 419-421. 